\title{
Повседневная жизнь в российском пограничье: мотивы и факторы трансграничных практик ${ }^{1}$
}

\author{
М.В. 3ОТОВА*, А.А. ГРИЦЕНКО**, А.Б. СЕБЕНЦОВ***
}

\begin{abstract}
*Мария Владимировна Зотова - кандидат географических наук, старший научный сотрудник, Институт географии РАН. Адрес: 119017, Москва, Старомонетный пер., д. 29. E-mail: zotova@igras.ru

**Антон Алексеевич Гриценко - кандидат географических наук, научный сотрудник, Институт географии РАН. Адрес: 119017, Москва, Старомонетный пер., д. 29. E-mail: antgritsenko@igras.ru

***Александр Борисович Себенцов - кандидат географических наук, старший научный сотрудник, Институт географии РАН. Адрес: 119017, Москва, Старомонетный пер., д. 29. E-mail: asebentsov@igras.ru
\end{abstract}

Цитирование: Зотова М.В, Гриценко А.А., Себенцов А.Б. (2018) Повседневная жизнь в российском пограничье: мотивы и факторы трансграничных практик // Мир России. T. 27. № 4. C. 56-77. DOI: 10.17323/1811-038X-2018-27-4-56-77

В статье рассматривается комплекс трансграничных практик локальных сообществ, определяюших специифику повседневной жизни населения приграничных регионов России и сопредельных с ней стран. На основе обширной эмпирической базы, собранной в ходе экспедиций и многочисленных интервью с экспертами, рассмотрены возможности и ограничения, которые создает гранииа, мотивы и факторы ее пересечения. Описаны ключевые цели пересечения российской границы местными жителями, в частности, связанные с получением разного рода услуг (образовательньх, медицинских и других), поездками на работу, шопингом и проведением досуга. Показано, что социально-экономические и соичиокультурные различия смежных государств стимулируют возникновение трансграничных практик, а свойства приграничных территорий (плотность населения, характер экономической жизни, наличие или отсутствие крупных городов и транспортных магистралей и прочее) дифференцируют их. Установлено, что отсутствие стимулов для пересечения гранииы может быть гораздо существеннее воздвигаемых препятствий. Авто-

\footnotetext{
1 Исследование выполнено в Институте географии РАН при финансовой поддержке Российского научного фонда в рамках проекта «Российское пограничье: вызовы соседства» (грант №14-18-03621). Сбор и анализ литературных источников для теоретического раздела (Опыт изучения социальных практик в исследованиях государственных границ) выполнен в рамках бюджетной темы «Пространственная динамика, градиенты и территориальные конфликты в современной России» № 01201356200 (№ 0148-2014-0014).
} 
ры подчеркивают конструктивную роль трансграничных практик населения в развитии добрососедских отношений, в сохранении критически необходимого уровня контактов, особенно в условиях политических кризисов.

Ключевые слова: государственная граница, трансграничные практики, российское пограничье, повседневная жизнь, рынок услуг, рынок труда

\section{Введение}

Маркиз де Кюстин в начале своего знаменитого травелога «Россия в 1839 году» приводит беседу с любекским трактирщиком, отмечающим различия в настроении русских, выезжающих за границу и возвращающихся домой, делая на этом основании выводы о жизни в России. «[К]огда они едут в Европу, вид у них веселый, свободный, довольный; <..> на обратном пути те же люди приезжают в Любек с вытянутыми, мрачными, мученическими лицами; < ..> вид у них озабоченный» [де Кюстин 1996, с. 62-63]. Важность этого проницательного наблюдения почти двухсотлетней давности не в остроумии оценок, а в констатации факта - пересечение границы, которое, соединяя ожидания и действительность, влияет на поведение и настроения людей. Одно дело, когда человек пересекает границу, эмигрируя, другое - отправляясь в командировку или отпуск, и третье, когда пересечение границы становится его привычкой или способом жизни [Бредникова 2008].

Приграничье - одно из немногих мест, где государственная политика и жизнь «маленького человека» тесно переплетены, а трансграничные практики становятся результирующей деятельностью разноуровневых социальных систем от государства и общества в целом до приграничных сообществ или трансграничных объединений. В условиях стабильности и устоявшегося социально-экономического порядка столь же упорядоченной является и жизнь приграничных сообществ, подчиняющаяся выработанным формальным и неформальным правилам. Но что происходит, когда привычный порядок рушится? Как местное население адаптируется к происходящим изменениям, которые переопределяют характер взаимодействий с соседями через границу?

Российская реальность дает богатую пищу для размышлений на эту тему. Всего четверть века назад границы с Норвегией, Финляндией, Польшей, Монголией и Китаем были «на замке» и непроницаемы для контактов населения (граница с КНДР до сих пор остается таковой). В то же время со странами Балтии, Южного Кавказа, Белоруссией, Украиной и Казахстаном границ вовсе не было, равно как и препятствий для многочисленных хозяйственных, бытовых, семейно-родственных, дружеских, образовательных и прочих связей. С окончанием советской эпохи все изменилось: закрытые межгосударственные границы преимущественно открылись, а открытые (административные) обрели жесткость межгосударственных, определив новые координаты окружающему миру. То, что еще вчера казалось «своим», в одночасье стало «чужим». Несмотря на сохранявшуюся «прозрачность», новые границы значительно затруднили экономические взаимодействия и перемещения людей между соседними территориями, что повсеместно привело к социальному и производственному кризису. 
Следующим важным событием стало расширение ЕС на восток. Вопреки декларациям о предстоящей либерализации режима внешних границ ЕС, он ужесточился по всему периметру новой Европы [Paasi 2009]. В «открытости границ для своих» и «закрытости границ для других» стали видеть инструмент и условие успешной интеграции новых членов ЕС [Cooper 2015]. Внешнеполитические события и (гео)политические сдвиги в отношениях России и соседних государств незамедлительно сказались на трансграничных практиках населения, меняя их интенсивность, характер и направления, переопределяя для жителей российского пограничья баланс между выгодами и издержками, мотивами и препятствиями пересечения границы.

\section{Опыт изучения социальных практик в исследованиях государственных границ}

Исследовательский интерес к политическим границам и разделительным линиям (лимология или Border Studies) переживает сегодня бурный рост по всему миру [Newman 2002]. Границам посвящено множество работ в самых разных отраслях гуманитарного знания. Особое место занимают работы по изучению трансграничных практик, которые структурируют социальное пространство и влияют на организацию повседневной жизни населения [Campbell 1992]. Интерес к ним объясняется в том числе необходимостью ответить на ряд фундаментальных вопросов, в разных аспектах волновавших Ф. Барта и его единомышленников (Г. Зиммеля, М. Фуко, Б. Андерсона и других): как сочетаются социальные и политические границы, где они совпадают и какую функцию выполняют во взаимоотношениях субъектов.

Начиная с 2000-х гг. на волне обсуждения путей и инструментов политической интеграции европейских государств усилия научного сообщества сосредоточились на изучении изменения режима границ, динамики их пересечения гражданами сопредельных стран и сопряженных с ними социальных представлений [Berg 2000]. В частности, А. Пааси выявил, что процессы социальной интеграции и дезинтеграции часто идут параллельно: одни практики работают на укрепление национальной идентичности и национального суверенитета, способствуя секьюритизации границ, в то время как другие направлены на поиск общих интересов, либерализацию пограничного режима и наращивание двусторонних контактов [Paasi, Prokkola 2008]. Обнаруженная взаимозависимость между режимом национальных границ и восприятием внешнего мира стимулировала изучение общественных дискурсов о сопредельных странах и регионах в прошлом и настоящем [Pfoser 2015; Newman, Paasi 1998]. Под пристальным вниманием исследователей оказались приграничные районы как зоны наиболее интенсивных международных обменов и взаимодействий, стягивающие потоки людей, товаров и услуг, идей и информации. Стали предприниматься попытки изучить субъективные мотивы пересечения границ местными жителями посредством анализа восприятия ими соседей и границы [Ghosh 2011]. Многообразие пограничных ситуаций вынуждало исследователей касаться этой темы при комплексном анализе отдельных участков пограничья [Domaniewski, Studzińska 2016; 
Laine 2016] или останавливаться на рассмотрении отдельных трансграничных практик, в частности, приграничном шопинге и трудовой миграции [Van der Velde, Spierings 2008]. При этом их обсуждение, как правило, концентрировалось вокруг вопросов интеграции и этнополитической консолидации, культурного разнообразия и устойчивости социальных границ [Cooper 2015; Andersen 2013]. Тем не менее за рамками этих дискуссий пока еще остается целый ряд тем, касающихся роли границ, соседства и трансграничных практик в жизни приграничных сообществ, связи внешних условий, представлений и образа жизни людей с пересечением государственных границ.

Приступая к исследованию, мы исходили из утверждения, что пересечение государственных границ для людей является априори обдуманным (субъективно рациональным) действием, в котором учитываются (перманентно взвешиваются) возможные выгоды и издержки. Мы предположили, что подвигающие к нему мотивы «потому что» и «для того чтобы», выделенные в свое время А. Шюцем для анализа человеческого поведения в повседневной жизни [Шюи 2004], определяются не только обыденными представлениями и практической необходимостью (желаниями и потребностями), но и объективными факторами (расстояниями, стоимостью, временными, психологическими и иными затратами), которые непременно должны приниматься субъектами в расчет. Наша гипотеза состояла в том, что локализация у государственной границы во многом влияет на характер и интенсивность трансграничных практик, определяя специфику жизни на приграничных территориях.

Мы рассматриваем трансграничные практики локальных сообществ, определяющие жизнь населения приграничных регионов России и сопредельных с нею стран. Неоднозначность процессов, происходящих на границе, когда соперничество принуждает к сотрудничеству, а сотрудничество происходит «поверх барьеров» [Вендина, Колосов 2007], обязывает нас погружаться в повседневность, изучать детали, причины пересечения границы, трудовые миграции, практики шопинга, досуга и прочее. При этом трансграничные практики мы понимаем как человеческую деятельность, связанную с пересечением границы в широком смысле, включая привычки людей, их поведение и программу действий. Была поставлена задача по возможности описать многообразие социальных практик, возникающих вблизи государственной границы, выявить цели, мотивы и факторы трансграничных перемещений на разных участках и определить их значение в жизни российского пограничья.

В первой части статьи выделяются возможности и ограничения, которые создает граница, мотивируя население к ее пересечению. Затем на примере различных ситуаций на российских границах подробно рассматриваются три основные сферы, которые объединяют практики, вызванные схожими факторами и едиными мотивами: (1) рынок услуг, (2) труд и неформальная занятость, (3) торговля и досуг. Во второй части анализируется, как широкое распространение трансграничных практик трансформирует приграничье: его внешний облик, социокультурные особенности и образ жизни населения. В третьей части систематизируются цели, мотивы и направления трансграничных практик по всем участкам российского пограничья, определяются факторы, сочетание которых формирует основные типы практик, характерных для тех или иных участков российской границы. 


\section{Информационные источники и методы исследования}

Исследование опирается на обширные полевые материалы, собранные авторами в период с 2010 по 2017 г. в приграничных регионах России и сопредельных стран ${ }^{2}$. Основными источниками информации стали экспертные интервью (суммарно около $600)$ с представителями местной исполнительной власти, научно-образовательной и культурной элиты, журналистами, сотрудниками таможенных служб, внешнеполитических ведомств и консульств, некоммерческих организаций, а также многочисленные беседы (полуструктурированные интервью) с местными жителями, которые регулярно пересекают границу в процессе исполнения своих рабочих обязанностей (таксистами, работниками гостиниц, предпринимателями), хозяйственно-бытовых дел, во время проведения досуга и иных видов повседневной деятельности.

Интервью проводились по единому гайду, включавшему следующие исследовательские вопросы (1) трансграничные потоки людей (объемы и динамика), (2) направления движения, (3) социальный портрет пересекающих границу, (4) цели и причины поездок, (5) стимулы и препятствия для поездок, механизмы разрешения затруднительных ситуаций, (6) логистические схемы, (7) контрабанда и теневой бизнес на границе, (8) приграничное сотрудничество и вовлеченность в него местного населения, (9) локальные аттракторы, (10) отношение к соседям, мифы и стереотипы, (11) влияние трансграничных связей на характер и ритм местной жизни.

Информация о трансграничных практиках населения также собиралась из открытых литературных и интернет-источников и дополнялась полевыми наблюдениями авторов в ходе посещения общественных мест (торговых объектов, бензоколонок, аптек, кафе, музеев), а также во время пересечения государственных границ. Особое внимание уделялось разговорам и поведению людей, элементам городской среды и символического ландшафта, предлагаемым населению товарам и услугам, уличным вывескам, рекламе и др.

Дополнительно были привлечены результаты репрезентативного опроса студенческой молодежи, проведенного авторами ${ }^{3}$ в 2012 г. среди студентов старших курсов Балтийского Федерального университета имени И. Канта, Гданьского и Клайпедского университетов, касающиеся восприятия соседей, опыта и мотивов пересечения границы (675 чел.: 252 - в Калининграде, 217 - в Гданьске и 206 в Клайпеде, средний возраст респондентов - 21 год).

2 Исследования проводились в городах, расположенные по обе стороны от российской границы с:

- Финляндией: Петрозаводске, Сортавала, Выборге, Светлогорске; Лаппеенранта, Йоэнсуу, Иматра;

- Польшей: Калининграде, Светогорске; Гданьске, Эльблонег, Гдыне, Сопоте;

- Эстонией: Ивангороде, Гдове, Пскове, Печоре; Нарве, Выру;

- Латвией: Пыталово, Себеже;

- Литвой: Советске;

- Белоруссией: Невеле, Смоленске, Клинцах, Новозыбкове; Гомеле, Добруше;

- Украиной: Стародубе, Почепе, Новозыбкове, Рыльске, Судже, Грайвороне, Белгороде, Ростове-на-Дону, Донецке (РФ), Симферополе, Джанкое; Чернигове, Новгороде-Северском, Глухове, Белополье, Сумах, Ахтырке,

Харькове и др.;

- государствами Южного Кавказа: Махачкале, Дербенте, Владикавказе, Нальчике; Степанцминде;

- Казахстаном: Оренбурге, Соль-Илецке, Черлаке, Омске, Барнауле; Уральске, Павлодаре;

- Китаем: Благовещенске, Хабаровске, Владивостоке; Хейхэ, Хуньчунь.

3 При деятельной поддержке профессора Г.М. Федорова (БФУ им. И. Канта), профессора Т. Пальмовского и профессора Я. Вендта (Гданьский университет), доктора Э. Спиряеваса (Клайпедский университет). 


\section{Условия жизни у границы и трансграничные практики}

Государственная граница диалектична по своей природе: с одной стороны, она обеспечивает безопасность, с другой, привлекает криминал и преступность. Выполняя функции фильтра, граница в идеале должна препятствовать распространению негативных практик (нелегальных миграций, контрабанды, криминальной деятельности), хотя в реальности она скорее способствует им. Кроме того, граница одновременно барьерна и контактна: любая граница представляет собой ограничитель или барьер, разделяющий территории. Ее наличие по определению усложняет взаимодействия, перемещения людей и грузов, экономические связи, так как ее пересечение требует значительных затрат времени, энергии и финансовых средств. Заинтересованность местных сообществ в поддержании добрососедских отношений, в сохранении дружеских, родственных и деловых трансграничных связей входит в очевидное противоречие с выполнением многочисленных функций границ - от обеспечения суверенитета и безопасности государства до формирования/поддержания национальной идентичности.

В то же время в силу своих свойств граница не только ограничивает, но и создает определенные возможности и повседневные практики, использующие выгоды соседства и не характерные для внутренних регионов страны. Под влиянием границы трансформируется повседневная жизнь населения, проживающего вблизи от нее. Социальная жизнь в приграничье во многом формируется благодаря наличию «соседей» [Бредникова 2008]. Пограничье является подвижным, гибким пространством, в котором друг на друга наслаиваются государственное и личное, «свое» и «чужое», где социальные процессы идут разнонаправленно и неоднозначно.

Близость к границе создает дополнительный спрос на товары и услуги, повышает туристический и экономический потенциал региона, позволяет компенсировать неустроенность повседневной жизни «дома» за счет использования возможностей потребительского рынка у «соседей», в том числе приобретения контрабандных товаров по более низким ценам. Кроме того, пограничье как зона контакта двух стран открывает возможности использования в свою пользу экономических, нормативных и других различий в ведении бизнеса, разницы в качестве и ценах на товары и услуги, формального и неформального рынка труда «соседа». Поликультурный состав населения создает дополнительные возможности развития в сфере культуры и образования. В свою очередь неустойчивость модели переноса потребления «за рубеж» в связи с волатильностью валют и изменчивостью геополитической ситуации стимулирует развитие локальной сферы услуг.

Рассуждения о влиянии границы на повседневную жизнь не всегда можно вести в однозначных терминах ограничений или возможностей, поскольку именно их сплав создает специфические условия трансграничной деятельности, определяя проблемы, нуждающиеся в разрешении. Наглядный пример - реализация в приграничных районах совместных проектов с участием обеих сторон. Их инициаторы и активные участники являются несомненными бенефициарами пограничной открытости, извлекая из этого как финансовые, так и моральные дивиденды. Однако сама потребность в такого рода деятельности не возникла бы, если бы не было проблем и ограничений, порожденных границами. 
Рассмотрим далее, какие возможности и ограничения создает граница, а также какие трансграничные практики возникают под влиянием ее свойств (барьерности, контактности и режима) и свойств прилегающих территорий соседних государств и взаимоотношений между ними (разницы в ценах, правилах и условиях ведения бизнеса, организации расселения и т.д.).

Рьнок услуг

Характерными чертами пограничья являются периферийность и удаленность от развитых рынков услуг. Топология и транспортная связанность территорий часто таковы, что для многих приграничных районов ближайшие экономические и культурные центры находятся за границей. Для жителей ряда приграничных районов Смоленской области удобнее и быстрее добраться до Витебска или Могилева, чем до Смоленска, а Брянской - до Гомеля. В Калининградской области такую альтернативу представляют центры ближайших польских воеводств, а в Псковской - латвийских краев. Жителям приграничья Северо-Западной области Казахстана удобнее ехать в Оренбург или Самару, а Атырауской - в Астрахань. Это, конечно, неудобно, но может оказаться гораздо менее затратным по времени и стоимости, чем решать возникшие проблемы в своей стране. Пересечение границы становится способом компенсации издержек: например, международные аэропорты Гданьска, Таллина, Риги, Витебска, Хэйхэ, Харбина, Улан-Батора, принимающие рейсы «лоу-костеров», обслуживают многих жителей из соседних приграничных регионов.

Медицинские услуги высокого уровня, особенно в сфере кардиологии, хирургии, эндопротезирования и стоматологии, трудно получить в средних и малых приграничных городах. Их жители стоят перед выбором, куда обратиться - в медицинское учреждение, расположенное в областном центре, или в зарубежное. Ответ зависит от многих личных причин, в том числе внутренних страхов и опасений, но фактом является и то, что жители Калининградской, Смоленской и Псковской областей все чаще обращаются за медицинскими услугами в приграничные центры Белоруссии, Эстонии, Латвии, Польши (здесь даже появился термин «родильный туризм»). Другая разновидность медицинского туризма - стоматологическая - получила развитие на границах с Китаем, где цены на услуги стоматологов ниже, качество обслуживания выше. На российско-казахстанской границе за медицинскими услугами (роды, операции на открытом сердце, диагностика и лечение онкологических заболеваний) едут в Россию. По данным сотрудников Оренбургского государственного университета, только в Центре микрохирургии глаза в Оренбурге ежегодно оперируют около 4 тыс. граждан Казахстана.

Граждане России активно осваивают возможности получения образования в соседних европейских, а в последнее время и китайских университетах. Вузы по другую сторону границы привлекают близостью к дому и более умеренной платой за обучение. Предлагая хорошее образование, они вполне конкурентоспособны по сравнению с российскими университетами, расположенными в крупных научнообразовательных центрах или столицах. Их преимущества - это близость к дому (возможность часто посещать родителей), приемлемая для родителей стоимость 
образования и проживания студента и менее высокие требования на вступительных экзаменах. По мнению многих местных экспертов, такой выбор - это удел выпускников со слабым аттестатом и детей из семей с невысоким заработком.

Есть и другие цели: например, карельские абитуриенты все чаще поступают в университеты Куопио, Миккели, Лаппеенранты, Иматры и Йоэнсуу, а калининградцы выбирают вузы Гданьска и Сопота. Как показали наши опросы студентов в Калининграде, их стремление переехать в другую страну вызвано не переживаемыми трудностями и плохими перспективами развития дома, а ожиданиями найти впоследствии высокооплачиваемую и интересную работу по специальности там, где (как им кажется) она есть у всех, и обучение в университетах стран ЕС - первый шаг на этом пути. Наличие диплома, признаваемого в западных странах, воспринимается как стартовое условие успешной карьеры и жизни в целом.

В российско-казахстанском и российско-белорусском пограничье ситуация обратная: казахстанцы и белорусы традиционно едут учиться в российские города (Омск, Оренбург, Смоленск). По информации местных экспертов, в трех ведущих вузах Смоленска учатся более полутора тысяч граждан Белоруссии, из них $70 \%$ приехали из Витебской и 20\% - из Могилевской областей; в Оренбургском и Омском государственных университетах ежегодно получают высшее образование более тысячи студентов из Казахстана. Обучение детей в крупных центрах соседней страны становится одной из многоцелевых и долговременных жизненных стратегий населения.

\section{Рьнок труда и неформальная занятость}

Смягчение пограничного режима на некоторых диадах российских границ, особенно введение режима местного приграничного передвижения (МПП) и облегчение процедуры выдачи виз, открыли для жителей приграничных районов новые возможности заработков - от трудоустройства на крупных предприятиях за границей до мелкой контрабанды, обеспечивающей самозанятость населения.

На границе Финляндии и Карелии благодаря различиям в ресурсной обеспеченности и условиях хозяйственной деятельности возник трансграничный комплекс производств, включающий заготовку леса на российской стороне и его переработку на финской. Хотя такое сотрудничество имело асимметричный характер, оно создало рабочие места в периферийных районах Карелии и глубоко повлияло на экономику и социальную жизнь республики. Если раньше главная ось развития Карелии была направлена вдоль полимагистрали Санкт-Петербург - Мурманск, то теперь в дополнение к ней сложились тесные широтные связи с приграничными районами Финляндии (число пересечений границы на карельско-финском участке за год превышает 2 млн при населении в 635 тыс. чел.), что существенно улучшает жизнь местного населения и позволяет малым городам у границы обрести второе дыхание [Толстогузов 2012; Колосов, Зотова, Вендина, Себенцуов 2016].

После распада СССР трудовые связи между приграничными городами и районами, расположенными близко друг к другу, стали довольно быстро ослабевать: на границах со странами Балтии из-за ужесточения режима границ, длительного время ожидания на пограничных переходах, а также трудностей легального 
трудоустройства иностранцев постоянная работа сменилась неофициальной и сезонной занятостью; до последнего времени наблюдались отдельные случае трансграничной занятости на российско-украинской границе: украинцы массово работали на сахарных заводах Курской области, а также на шахтах Ростовской области. До начала 2000-х гг. на шахты Гуково, где оплата труда была выше, чем на Украине, ежедневно доставляли рабочих из соседних городов Луганской области, однако административные сложности свели завоз иностранной рабочей силы к минимуму [Колосов 2016].

После событий 2014 г. пересечение российско-украинской границы стало преимущественно односторонним: около 80\% пересекающих границу составляют граждане Украины, которые едут в Россию на заработки ${ }^{4}$ Большая часть трудоспособных мигрантов расселяется в Белгородской области в пределах наиболее экономически развитых ареалов (Белгород, Белгородский, Шебекинский, Старооскольский районы). Выходцы из Украины часто не заинтересованы в получении российского гражданства, не хотят легализоваться и получать статус беженца. Как правило, они предпочитают временную работу, так как планируют вернуться на Украину, а российское гражданство и официальная регистрация существенно осложняют поездки на родину.

На границе широко распространены и неформальные виды трудовой деятельности - челночная торговля и теневой бизнес: поставка дешевой ликероводочной и кондитерской продукции из Казахстана, теневая продажа морепродуктов на Дальнем Востоке, водки и сигарет из Калининграда в Польшу, из ЛНР и ДНР в РФ, ввоз подержанных машин из ЕС и Японии, практиковавшийся до 2009 г. в силу низких ввозных пошлин, и покупка автомобиля (доверенности на управление) на другой стороне границы (в основном в Польше и странах Балтии) без его оформления «дома», а также серые схемы экспорта леса в Китай: среди поставщиков кругляка в Китай из Читинской области немало сельских жителей пограничья, на мотоциклах вывозящих на лесоприемный пункт по одному-два бревна, чтобы получить пару тысяч рублей [Янков 2010].

Причиняя заметный ущерб экономике приграничных регионов и подрывая деятельность некоторых местных предприятий (особенно в сфере пищевой промышленности), теневой бизнес является источником доходов значительной части местного населения. Это не только личная «подушка безопасности», но и фактор социально-экономической стабильности приграничных районов, обеспечения самозанятости населения и поддержания привычного уровня жизни. Все это заставляет местную администрацию смотреть сквозь пальцы на то, что является недопустимым с точки зрения региональных или федеральных властей. Эти соображения касаются и многочисленных посреднических услуг по оформлению различных документов, в том числе международных страховок, необходимых для пребывания в соседней стране, консультационных и юридических услуг по открытию бизнеса предпринимателями, услуг переводчиков (особенно на российско-китайской границе), риэлтеров при покупке недвижимости в соседней стране (преимущественно в Финляндии и Эстонии).

\footnotetext{
4 По информации начальника отдела международных связей и приграничного сотрудничества Белгородской области, январь 2016 г.
} 
Граница диверсифицирует и модифицирует рынок труда, создавая работу для местных жителей (пограничная и таможенная службы) и привлекая жителей из-за рубежа, из приграничных регионов соседних государств; она стимулирует и местный рынок труда, приводя к развитию тех объектов, спрос на которые высок в конкретных условиях: так, на границе со странами ЕС зафиксировано заметно больше аптек и автозаправок, чем на других участках пограничья. При активном развитии трансграничных связей жизнь приграничья нанизывается на трансграничные практики, стимулируя торговлю и сферу услуг.

\section{Потребление и досуг}

Жизнь у границы существенно меняет характер потребления местных жителей. Разница в ценах дает возможность экономить, а богатство выбора повышает удовлетворенность жизнью. Потребительский туризм стал одним из самых популярных мотивов пересечения границы, особенно на границах России со странами ЕС и Китаем. Приобретаемые в Европе товары, по мнению местных жителей, обладают более высокими потребительскими свойствами, чем российские аналоги Однако, в отличие от россиян, которым европейская продукция кажется лучше отечественной, финны и поляки не верят в качество российских продуктов (молока, мяса), а также в уровень организации санитарного контроля, поэтому даже разница в ценах не приводит к росту потребительского спроса с их стороны. В то же время казахи и ,vvghn подчеркивают высокое качество отдельных российских продуктов (пива, шоколада, кондитерских изделий), сравнивая их с местными аналогами 6 .

Направление трансграничных потоков за покупками сильно зависит от экономической конъюнктуры и колебаний курса валют. Если до 2014 г., ознаменовавшегося не только украинским кризисом, но и падением цен на нефть, а следом и понижением курса рубля, за покупками заграницу ездили преимущественно россияне, то в конце 2014 г. наблюдался существенный приток в Россию из Китая, Казахстана, Белоруссии, Азербайджана и стран Балтии. В Благовещенске за первое полугодие 2015 г. количество китайских шопинг-туристов выросло в 2,5 раза $^{7}$.

Одновременно поток жителей российского приграничья в соседние регионы ЕС и Китая сократился, но не кардинально, поскольку сформировавшаяся привычка к потреблению за рубежом представлялась весьма устойчивой. Даже отмена польской стороной в июле 2016 г. режима МПП, которая означала для россиян возрастание трудностей с оформлением виз, а для поляков - падение покупательского спроса в приграничных супермаркетах, не привела к радикальному изменению

\footnotetext{
5 Так, на российско-финской границе бытует миф, что финский Fairy моет посуду гораздо лучше сделанного в России, а продающийся в Финляндии Nescafe невозможно сравнить по вкусу с тем, что продается в России. В Калининградской области уверены, что сосиски из польского дискаунтера содержат больше мяса, чем купленные в местном магазине

6 Китайцы, например, считают, что в российских продуктах меньше пестицидов. Кроме того, многие российские товары (мука, молочные продукты, сгущенка, йогурты) пользуются большим спросом у китайцев как экзотические.

7 Глава Приморья: число китайских туристов в крае увеличилось в 2,5 раза // Рамблер.финансы. 5 сентября 2015 // https://finance.rambler.ru/news/1676585/https://finance.rambler.ru/news/1676585/
} 
ситуации. Расходы калининградцев в магазинах по другую сторону границы в третьем квартале 2016 г. сократились всего на 15,3\% по сравнению с аналогичным периодом 2015 г. [Razowski 2017], однако число поляков, приезжающих за бензином в Калининградскую область, резко уменьшилось. Это наглядно свидетельствует о том, что сильные мотивы стимулируют преодолевать препятствия, а не очень сильные - искать альтернативу.

Не только выгодные покупки определяют привычку россиян выезжать в соседние страны, это и возможность сменить обстановку. «Развлекающийся покупатель» или «отдыхающий покупатель», совмещающий сразу несколько целей поездки, - явление, весьма распространенное в пограничье [Van der Velde, Spierings 2008]. Перспектива побывать на чужой территории и получить новые ощущения побуждают жителей пересекать границы не только с целью покупок, но и для получения разнообразных услуг и развлечений (посещение кафе, музеев, культурных мероприятий и концертов). Такая модель поведения диктуется стремлением оптимизировать затраты свободного времени.

Экономические мотивы в пользу совмещения покупок и отдыха могут принципиально различаться по разные стороны границы. Так, испытывая потребность в смене обстановки, россияне едут в Финляндию или Польшу скорее с целью потратить деньги, а финны или поляки - скорее экономить, учитывая значительную разницу в стоимости сервиса [Izotov, Laine 2012]. На российско-казахстанской границе соображения экономии становятся более существенными для россиян (так же, как и на российско-китайской границе) [Симутина, Рыжова 2007]. Эти различия в поведении, а также сам облик «подгулявших» людей, тратящих деньги на безделушки или считающих «копейки», рождают у жителей пограничья - экспертов в сфере контактов с соседней страной - негативные этностереотипы, транслирующиеся всем остальным, примерно так же, как любекский трактирщик, о котором упоминалось вначале, рассказывал маркизу де Кюстину о России, в которой он никогда не бывал.

Отсутствие адекватных знаний о соседней стране порождает стереотипные общественные представления о ней и может быть серьезным препятствием для повседневных взаимодействий, например, из-за неприязни или отсутствия интереса. Наш опрос студентов в Гданьске, показал, что слабый интерес к Калининграду у польских респондентов основан на его негативном образе в их представлениях: в молодежной среде распространены клише, связанные не столько с соседним регионом, сколько с имиджем России в целом. У 27\% опрошенных студентов слово «Калининград» вызвало следующие негативные ассоциации: водка, пьянство, холод, мафия, бедность, низкий уровень жизни, контрабанда, теневая экономика и прочее. Похожую предвзятость можно встретить в финском и норвежском пограничье [Laine 2016]. На российско-китайской границе не менее ярко проявляется глубоко укорененный взаимный страх - китайцев перед «угрозой с севера» и россиян перед «желтой опасностью» [Ларин 2008].

С другой стороны, слабое знакомство с соседом может порождать и интерес к нему, став важным фактором, определяющим повседневные практики населения [Andersen 2013]. Так, на российско-китайской границе взаимный интерес друг к другу подогревается экзотичностью культуры соседней страны, а на границах с ЕС работает сочетание факторов - регион в меру знаком и одновременно неизвестен. Жители Карелии, Калининградской и Ленинградской областей охотно отдыхают 
на Балтийском побережье Польши, пользуются возможностями сельского туризма в Варминско-Мазурском воеводстве, аквапарков и спа-центров Финляндии.

Довольно редкой, но от этого не менее важной целью пересечения границы для определенных групп людей становится паломничество: людей привлекают святые места, например, Печерский монастырь (Псковская область), Коренная пустынь (Курская область), Иволгинский дацан (Республика Бурятия) и монастырь Амарбаясгалант (Монголия).

Распространенной целью поездок на другую сторону границы является желание навестить родных и близких, посетить могилы предков. Такие поездки совершаются чаще всего на постсоветских границах России, что связано с тесными семейными и многочисленными родственными связями между людьми, проживающими в соседних районах.

\section{Трансформация пограничья под влиянием повседневных практик}

Наличие государственной границы оказывает заметное влияние на жизнь приграничных сообществ. Согласно концепции «знакомой среды» (familiarity), слишком значительные или многочисленные различия при сохранении заметных социокультурных границ, с одной стороны, могут сдерживать отдыхающих потребителей от посещения «чужих» мест и привести к ментальным границам, которые негативно влияют на трансграничные взаимодействия [Van der Velde, Spierings 2008]. С другой стороны, когда неизвестность места растворяется, его привлекательность для посетителей из-за границы тоже может исчезнуть. Потребители часто ищут «ожидаемое неожиданное», чтобы чувствовать себя вне дома как дома, не испытывая культурного шока [Houtum Van, Van der Velde 2004]. Трата времени и денег за границей должна в значительной степени быть «знакомой» потребителям, но в придачу иметь и некоторую специфику.

Опыт первой поездки за границу - это всегда стресс, связанный с множеством непониманий: другие язык и деньги, неизвестные товары, незнакомые правила поведения. Но по мере повторения эксперимента приходит узнавание, культурный шок исчезает, человек начинает искать «что-то новенькое», еще не знакомое, чувствуя себя за рубежом одновременно дома и не дома. Визуальные и социокультурные различия перестают восприниматься с тревогой, ощущения окрашиваются в позитивные тона, а поездка за границу становится безопасным приключением, вроде выезда на природу или турпохода. Этому способствует и маркетинговая политика, ориентированная на привлечение покупателей из другой страны и создание для них психологического комфорта. В магазинах и ресторанах Гданьска, Гдыни и Эльблонга (Польша), Йоэнсуу, Лаппеенранты и Иматры (Финляндия), Хэйхэ и Суйфэньхэ (Китай) обязательными атрибутами стали вывески, меню, реклама на русском языке, работают русскоязычные служащие. На главной торговой улице Хэйхэ установлен памятник А.С. Пушкину, самые популярные рестораны называются по-русски - «Музыка» и «Березка», а косметические салоны носят женские славянские имена. В Варминско-Мазурском и Поморском воеводствах Польши появилась программа сертификации «Russian Friendly: здравствуйте!», объединяющая объекты, подготовленные к обслуживанию русскоязычных туристов. 
Соседство с другим государством напоминает о себе многочисленными визитерами, приемом зарубежного теле- и радиовещания. Происходит спонтанное общение с носителями другого языка на улицах, рынках, в транспорте, кафе и магазинах. Оно приводит к освоению отдельных иностранных слов, облегчающих взаимопонимание, и к формированию локальных «пиджинов», обеспечивающих контакт при незнании (или слабом знании) языков и отсутствии мотивации к их изучению. Показательны русско-китайские, русско-казахские [Герасименко, Филимонова 2011], русско-норвежские и прочие смеси. В Приамурье русско-китайский «пиджин» имел широкое распространение вплоть до 1930-х гг., затем был практически забыт и вновь стал восстанавливаться в 1990-е гг. [Оглезнева 2011].

В то же время этнокультурная контрастность границы стимулирует необходимость полноценного изучения языка партнера. Востребованность преподавателей иностранных языков растет, их изучение перемещается с улицы, где происходит спонтанное общение с носителями языка, в образовательные учреждения. Языковая компетентность становится условием успешной карьеры. Этот процесс происходит практически вдоль всей линии российской границы с обеих ее сторон. Исключением, пожалуй, являются только российско-белорусское и российскоукраинское пограничье, где доминирование русского языка в повседневной жизни препятствует повышению статуса языка соседей как «достойного» изучения.

Постепенное освоение повседневных практик, распространенных в соседней стране, и накопление знаний о них приводят к формированию внутреннего запроса на то, чтобы собственная жизнь была не хуже, чем «у людей». Возникает «демонстрационный эффект» - заразительное влияние другого образа жизни и способа потребления, которые оцениваются как более современные и привлекательные. Такое воздействие в первую очередь сказывается на поведении отдельных людей, меняя стандарты их потребления и привычки - от еды и одежды до досуга и здорового образа жизни, затем проникает в бизнес и сервис (кафе, фестивали, магазины) и, наконец, городскую политику и благоустройство. Приграничные районы втягиваются в постоянный диалог, заимствуя друг у друга отдельные черты организации городской среды через обоюдный процесс имитации и дифференциации [Бийе 2014] ${ }^{8}$.

Влияние соседа проявляется и в осознании выгодности культурных репрезентаций для развития и поддержания собственного туризма. Культурный рубеж границы может быть скопирован в приграничную зону, давая возможность без ее пересечения соприкоснуться с соседом, обеспечивая импорт потенциального внешнего туризма. Псевдо-этнографический бизнес позволяет достигнуть сразу нескольких целей - повысить привлекательность места за счет его отличительности, реанимировать остатки культурного наследия и создать возможность побывать «за границей» для тех, у кого недостаточно средств или смелости. В результате усложнения процедуры пересечения границы с Украиной в Белгородской области (в первую очередь в Грайворонском районе) благодаря пространственной и культурной близости (распространение блюд украинской кухни и схожие культурные

\footnotetext{
8 Так, в Благовещенске по примеру китайских соседей обустроили часть набережной, осветили здания и стали использовать громкую музыку в общественных местах. В Хэйхэ появилась городская скульптура - элемент городской среды, привычный для россиян, но необычный для китайских городов. В Ивангороде по примеру соседней Нарвы развивается велосипедный туризм, организован прокат велосипедов, созданы велодорожки. В приграничных городах Польши увеличили время работы кафе и ресторанов.
} 
традиции) получил распространение новый туристический продукт - украинский «ностальгический» туризм [Заяи, Зотова, Туров, Ключников 2017]. Китайский Хэйхэ, известный в Китае как «окно в Европу», привлекает китайских туристов возможностью «посетить» Россию и обзавестись русскими сувенирами, не пересекая границу и не получая заграничного паспорта.

Совместные мероприятия по обе стороны границы, приуроченные к крупным праздникам (например, окончанию Второй мировой войны), носят в пограничье важную объединяющую функцию. Несмотря на то, что в Эстонии, как и во всей Европе, празднуют 8 мая, жители Нарвы и Ивангорода вместе отмечают День Победы 9 мая. На эстонской территории тысячи жителей приносят цветы и возлагают венки к могилам павших советских солдат, Посольство РФ организует приемы и концерты для ветеранов. По инициативе локального сообщества создана практика демонстрации общности исторического прошлого и культурного единства между русскоязычным населением северо-востока Эстонии и российского пограничья. На российскоукраинской границе, помимо Дня Победы, подобным объединяющим праздником до событий 2014 г. был Пасхальный крестный ход с Пряжевской иконой Божьей Матери из российского села Горналь в украинское Мирополье - единственный крестный ход, совершавшийся с 2002 по 2014 г. через государственную границу России.

\section{Цели и направления трансграничных практик в российском пограничье}

По данным ФТС РФ и ПС ФСБ РФ, в 2013 г. общее число пересечений российской границы через сухопутные пункты пропуска превысило 75 млн. Существенная часть этого потока приходилась на жителей приграничных регионов, при этом распределение по участкам границы носило неравномерный характер (рисунок 1). Наши исследования показывают, что основные цели пересечения границы и посещения соседнего государства - (1) трудовая деятельность, (2) получение образования, (3) получение медицинских услуг, (4) покупка продовольственных и других потребительских товаров, (5) покупка топлива, (6) удовлетворение досуговых потребностей, (7) паломничество, (8) посещение друзей и родственников, семейных могил (таблица 1, стр. 71).

Контрасты в территориальной структуре расселения и хозяйства, социальноэкономической ситуации в соседних странах и регионах приводят к асимметричному характеру трансграничных практик. Зеркальными остаются только поездки с целью посещения родственников, а также покупки товаров и проведения досуга. Визиты к родственникам характерны в основном для постсоветского пространства, где граница разделила в прошлом единую территорию. В то же время уникальность сочетаний в значительной мере определяется различиями в мотивах, побуждающих пересекать границу, и ролью этих практик в жизни приграничных сообществ.

Цели поездок существенно различаются по направлениям. Из России, как правило, едут навестить родственников, а также за развлечениями и покупками; остальные цели (паломничество, трудовая деятельность, получение медицинских и образовательных услуг) носят эпизодический характер и встречаются только на некоторых участках. 


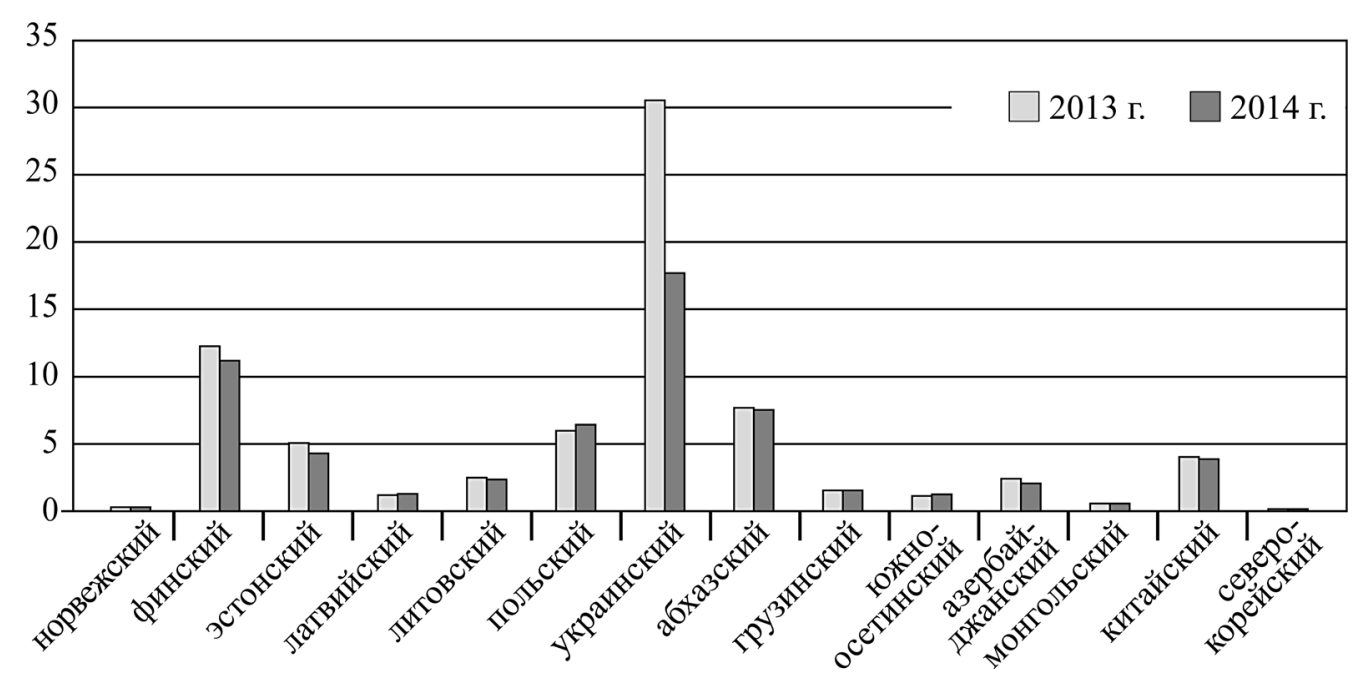

Рисунок 1. Динамика пересечений границы России физическими лицами через сухопутные и смешанные пункты пропуска в 2013-2014 гг., млн пересечений

Источник: расчеты авторов на основе данных Федерального агентства по обустройству государственной границы РФ (Росграницы).

Из приграничных регионов стран бывшего СССР (за исключением стран Балтии) жители едут в Россию с более разнообразными целями: в поисках заработков, за медицинскими услугами, образованием, покупкой товаров и бензина, развлечениями. Однако характер и интенсивность этих поездок сильно зависят от конкретных условий пересечения границы: например, на российско-грузинском участке из-за отсутствия дипломатических отношений и сложности получения грузинами российской визы регулярные практики посещения приграничных российских регионов практически отсутствуют, а россияне, напротив, могут посещать Грузию без виз. Учитывая разницу в ценах на продукты и развитие горнолыжного туризма, здесь наиболее распространены поездки за покупками и проведением досуга. Кроме того, на Кавказе, несмотря на институциональные ограничения, продолжают поддерживаться родственные связи разделенных народов (осетины, грузины, лезгины).

Для стран ЕС и Норвегии Россия не является очень привлекательной страной, и поездки иностранцев, как правило, ограничиваются ближайшими населенными пунктами (Сортавала, Выборг, Светогорск на российско-финской границе, Мамоново - на российско-польской, Ивангород и Печоры - на российско-эстонской) и связаны с покупкой более дешевого бензина, сигарет и алкоголя, а также с получением специфических услуг, преимущественно стигматизированных (трансграничная проституция и сопутствующие развлечения).

На всех участках российских границ главные мотивы трансграничных практик населения связаны с желанием сократить транспортные и финансовые издержки, восполнить отсутствие или разнообразить выбор товаров и услуг, а также повысить их качество. 
Таблица 1. Цели и направления трансграничных поездок населения российского пограничья

\begin{tabular}{|c|c|c|c|c|c|c|c|c|c|c|c|c|c|c|c|c|}
\hline \multirow{3}{*}{$\begin{array}{l}\text { Участки российской } \\
\text { границы }\end{array}$} & \multicolumn{16}{|c|}{ Цели трансграничных поездок } \\
\hline & \multicolumn{8}{|c|}{ из России } & \multicolumn{8}{|c|}{ в Россию } \\
\hline & 1 & 2 & 3 & 4 & 5 & 6 & 7 & 8 & 8 & 7 & 6 & 5 & 4 & 3 & 2 & 1 \\
\hline Норвежский & & & & & & & & & & & & & & & & \\
\hline Финский & & & & & & & & & & & & & & & & \\
\hline Эстонский & & & & & & & & & & & & & & & & \\
\hline Латвийский & & & & & & & & & & & & & & & & \\
\hline Литовский & & & & & & & & & & & & & & & & \\
\hline Польский & & & & & & & & & & & & & & & & \\
\hline Белорусский & & & & & & & & & & & & & & & & \\
\hline Украинский & & & & & & & & & & & & & & & & \\
\hline Абхазский & & & & & & & & & & & & & & & & \\
\hline Грузинский & & & & & & & & & & & & & & & & \\
\hline Югоосетинский & & & & & & & & & & & & & & & & \\
\hline Азербайджанский & & & & & & & & & & & & & & & & \\
\hline Казахстанский & & & & & & & & & & & & & & & & \\
\hline Монгольский & & & & & & & & & & & & & & & & \\
\hline Китайский & & & & & & & & & & & & & & & & \\
\hline Северокорейский & & & & & & & & & & & & & & & & \\
\hline
\end{tabular}

Источник: составлено авторами на основе экспертных оценок и экспедиционных наблюдений. 
Большое значение для трансграничных практик имеет отношение к соседним территориям как к экономическим и/или культурным центрам или перифериям. Частота и разнообразие поездок выше на тех участках, где регионы и города по ту сторону границы воспринимаются соседями в качестве центра, кроме того, определенную роль играет общее отношение к соседнему государству. Субъективное желание жить «как в Европе» часто оказывается наиболее важным мотивом трансграничных поездок. Особенно ярко это проявляется в Калининградской области (в силу ее эксклавности), жители которой удовлетворяют свои потребности (в том числе в области медицины, образования, проведения досуга и покупки товаров) в соседних польских воеводствах. Соседние города Польши Гданьск, Гдыня, Сопот, Ольштын стали выполнять для калининградцев функцию региональных экономических центров, а сама Польша - культурного ориентира (особенно для молодежи). Для жителей приграничных регионов Казахстана, Белоруссии, Украины, а также Абхазии и Южной Осетии, таковыми по-прежнему остаются российские города.

\section{Заключение}

Превращение границы из линии (полосы), разделяющей государства, в пространство интенсивных контактов и взаимодействий людей кардинально меняет их жизнь. Жители приграничных районов начинают использовать выгоды этого соседства: разницы цен, возможностей и обустройства жизни. Даже те, кто никак не участвует в трансграничных перемещениях, обменах и коммуникациях, получают свою частичку пограничной ренты, которая перераспределяется от коммьютеров («челноков») к членам их ближайшего круга, а также в другие сферы местной экономики.

Отсутствие стимулов для пересечения границы может быть гораздо важнее препятствий, с которыми люди сталкиваются при преодолении государственных рубежей. Снятие пограничных барьеров при слабых стимулах их преодоления ничего не меняет, тогда как наличие сильных стимулов заставляет включать фактор границы в число неизбежных социальных издержек, возникающих на пути достижения поставленной цели.

Исследуя многообразие целей и мотивов пересечения границы местными жителями, было выявлено, что стихийные ренто-спекулятивные отношения («купить дешевле - продать дороже»), соединяющие разграниченные территории и поддерживающие достигнутый уровень жизни местного населения, типичные для первого постсоветского десятилетия, сменились многообразными взаимодействиями, связанными с развитием малого бизнеса, услуг и туризма. Тем не менее использование разницы в ценах остается важным стимулом приграничных обменов и на «старых», и на «новых» границах России. Столь же сильные изменения коснулись и практик, базировавшихся на семейно-родственных, дружеских и профессиональных связях. Поколения, которые связывало общее советское прошлое, учеба в университетах и работа на предприятиях, по мере старения утрачивают свои консолидированные позиции и сходят со сцены. Их наследники движимы другими мотивами и интересами, придерживаются иных эмоциональных и прагматических ориентиров. Однако и этот тип трансграничных взаимодействий 
сохраняет свое значение благодаря смешанным бракам и новым волнам миграции в соседние страны. Наиболее устойчивыми остаются социальные практики, компенсирующие дефицит качественных услуг и создающие своеобразный симбиоз приграничных сообществ.

Несмотря на все многообразие ситуаций на российских границах, трансграничные практики составляют общий фон, объединяющий все пограничье. С одной стороны, они очень волатильны и подвижны и могут быстро меняться в зависимости от международной обстановки и двусторонних отношений, состояния экономики сопредельных стран и регионов, курсов валют, уровня цен, таможенных пошлин, транспортных тарифов, с другой, очень устойчивы. Они столь прочно вошли в жизнь приграничных сообществ, что люди уже не могут существовать без использования преимуществ приграничного положения, и даже существенные (но не радикальные, как в случае с Украиной) изменения режима границ не оказывают на них значительного влияния.

Кризисные явления и острые конфликты на межгосударственном уровне не приводят к тотальному свертыванию трансграничных взаимодействий. Повседневные потребности людей и нужды экономики, накопленный за предыдущие годы позитивный опыт взаимодействий через границу способствуют сохранению критически необходимого уровня контактов. Отношение к «хорошему соседу» в меньшей степени подвержено ситуативным изменениям, чем отношение к соседнему государству, которое легко меняет свое дружественное расположение.

Партнерство между странами, создавая определенные предпосылки для активизации местных взаимодействий, не всегда приводит к росту их интенсивности. Характерный пример - российско-казахстанская граница, где процессы «банализации» границы значительно менее выражены, чем в российско-польском или российско-китайском пограничье. Причины - низкая плотность хозяйственной деятельности, большие расстояния между крупными городами, слабость инфраструктуры и низкая мобильность населения.

Повседневные трансграничные контакты населения, увеличивая возможности реализации жизненных планов и потребностей, способствуют росту удовлетворенности жизнью. Дело не только в том, что трансграничные практики создают дополнительные источники доходов, но и в обретении людьми опыта действий в иной социальной среде, в появлении интереса и доверия друг к другу, в поддержании взаимовыгодных и добрососедских отношений и в формировании идентичности «трансграничного жителя», которому комфортно по обе стороны границы.

\section{Литература}

Бийе Ф. (2014) Современность в пространственном измерении: открытые рынки, герметичность и вертикальность в двух приграничных городах России и Китая // Экономическая социология. Т. 15. № 2. С. 76-95.

Бредникова О.Е. (2008) Приграничье как социальный феномен (направления социологической концептуализации) // Вестник Санкт-Петербургского университета. Сер. 12. Вып. 4. С. 492-497.

Вендина О.И., Колосов В.А. (2007) Партнерство в обход барьеров // Россия в глобальной политике. Т. 5. № 1. С. 142-154. 
Герасименко Т.И., Филимонова И.Ю. (2011) Оренбургско-казахстанское порубежье: историко-этнографический и этногеографический аспекты. Оренбург: Оренбургский гос. университет.

Заяц Д.В., Зотова М.В., Туров Н.Л., Ключников М.И. (2017) Кризис российско-украинских отношений: последствия для трансграничных взаимодействий в Белгородской области // Известия РАН. Серия географическая. № 5. С. 43-57.

Колосов В.А. (2016) Трансграничная регионализация и фронтальерские миграции: европейский опыт для России? // Региональные исследования. № 3 (53). С. 83-93.

Колосов В.А., Зотова М.В., Вендина О.И., Себенцов А.Б. (2016) Российское пограничье: современные вызовы и подходы к изучению // Котляков В.М., Стрелецкий В.Н., Глезер О.Б., Сафронов С.Г. (ред.) Проблемы регионального развития России. М.: Кодекс. C. 234-256.

Кюстин де А. (1996) Россия в 1839. В двух томах. Т. 1. М.: Изд-во им. Сабашниковых.

Ларин В.Л. (2008) Межрегиональное взаимодействие России и Китая в начале XXI века: опыт, проблемы, перспективы // Проблемы Дальнего Востока. № 2. С. 40-53.

Оглезнева Е.А. (2011) Языковая ситуация в Приамурье: динамический аспект. Историко-лингвистический очерк // Слово: фольклорно-диалектологический альманах. № 9. С. 7-25.

Симутина Н.Л., Рыжова Н.П. (2007) Экономические и социальные взаимодействия на трансграничном пространстве Благовещенск-Хэйхэ // Вестник ДВО РАН. № 5. C. $130-144$.

Толстогузов О.В. (2012) Регион в условиях глобализации: пространственный и институциональный аспекты // Труды КарНЦ РАН. № 6. Сер. «Регион: экономика и управление». С. 19-28.

Шюц А. (2004) Обыденная и научная интерпретация человеческого действия // Шюц А. Избранное: Мир, светящийся смыслом. М.: РОССПЭН. С. 7-50.

Янков А.Г. (2010) Синофобия-русофобия: реальность и иллюзии // Социологические исследования. № 3. С. 65-71.

Andersen D.J. (2013) Exploring the Concept of (Un)familiarity: (Un)familiarity in Border Practices and Identity-Formation at the Slovenian-Croatian Border on Istria // European Planning Studies, vol. 21, no 1, pp. 42-57.

Campbell D. (1992) Writing Security. United States Foreign Policy and the Politics of Identity. Bloomington, IN: Indiana University Press

Cooper A. (2015) Where Are Europe's New Borders? Ontology, Methodology and Framing // Journal of Contemporary European Studies, vol. 23, no 4, pp. 447-458.

Domaniewski S., Studzińska D. (2016) The Small Border Traffic Zone between Poland and Kaliningrad Region (Russia): The Impact of a Local Visa-Free Border Regime // Geopolitics, vol. 21, no 3, pp. 538-555.

Ghosh S. (2011) Cross-border Activities in Everyday Life: the Bengal Borderland // Contemporary South Asia, vol. 19, no 1, pp. 49-60.

Houtum H., Van der Velde M. (2004) The Power of Cross-border Labour Market Immobility // Tijdschrift voor Economische en Sociale Geografie, vol. 95, no 1, pp. 100-107.

Izotov A., Laine J. (2012) Constructing (Un) familiarity: Role of Tourism in Identity and Region Building at the Finnish-Russian Border // European Planning Studies, vol. 21, no 1, pp. 93-111.

Laine J. (2016) Threats, Challenges, and Finnish-Russian Cross-Border Security Cooperation: A Finnish Perspective // Tourism and Geopolitics: Issues and Concepts from Central and Eastern Europe (ed. Hall D.), pp. 178-191.

Newman D. (2002) The Lines that Separate: Boundaries and Borders in Political Geography // A Companion to Political Geography (eds. Agnew J., Toal G.). Oxford: Blackwell, pp. 23-43.

Newman D., Paasi A. (1998) Fences and Neighbours in the Postmodern World: Boundary Narratives in Political Geography // Progress in Human Geography, vol. 22, no 2, pp. 186-207.

Paasi A. (2009) Bounded Spaces in a 'Borderless World': Border Studies, Power and the Anatomy of Territory // Journal of Power, vol. 2, no 2, pp. 213-234.

Paasi A., Prokkola E.-K. (2008) Territorial Dynamics, Cross-border Work and Everyday Life in the Finnish-Swedish Border Area // Space and Polity, vol. 12, no 1, pp. 13-29. 
Pfoser A. (2015) Between Security and Mobility: Negotiating a Hardening Border Regime in the Russian-Estonian Borderland // Journal of Ethnic and Migration Studies, vol. 41, no 10, pp. 1684-1702.

Razowski Ł. (2017) Pół roku bez małego ruchu granicznego. Resort podsumowuje zyski i straty // Olsztyn Onet // http://olsztyn.onet.pl/pol-roku-bez-malego-ruchu-granicznegoresort-podsumowuje-zyski-i-straty/196zwdm

Van der Velde B., Spierings B. (2008) Cross Border Shopping and the "Bandwith of Familiarity": Exploring the Positive Impact of National Borders on Consumer Mobility in the Euregion Rhine-Waal. Nijmegen: Nijmegen School of Management // http://hdl.handle.net/2066/69012

\title{
Everyday Life in the Russian Borderlands: the Motives and Determinants of Cross-border Practices
}

\author{
M. ZOTOVA*, A. GRITSENKO**, A. SEBENTSOV***
}

\begin{abstract}
*Maria Zotova - PhD in Geography, Senior Researcher, Institute of Geography, Russian Academy of Sciences. Address: 29, Staromonetnyi Lane, Moscow, 119017, Russian Federation. E-mail: zotova@igras.ru

**Anton Gritsenko - PhD in Geography, Researcher, Institute of Geography, Russian Academy of Sciences. Address: 29, Staromonetnyi Lane, Moscow, 119017, Russian Federation. E-mail: antgritsenko@gmail.com

***Aleksander Sebentsov - PhD in Geography, Senior Researcher, Institute of Geography, Russian Academy of Sciences. Address: 29, Staromonetnyi Lane, Moscow, 119017, Russian Federation. E-mail: asebentsov@gmail.com
\end{abstract}

Citation: Zotova M., Gritsenko A., Sebentsov A. (2018) Everyday Life in the Russian Borderlands: the Motives and Determinants of Cross-border Practices. Mir Rossii, vol. 27, no 4, pp. 56-77 (in Russian). DOI: 10.17323/1811-038X-2018-27-4-56-77

\begin{abstract}
This article focuses on the cross-border practices of communities, i.e. practices which constitute the core of everyday life in the Russian border regions. The study is based on surveys and interviews with experts conducted by the authors in 2000-2010 both in the border regions of Russia and neighboring countries. The article analyzes the opportunities and constraints of living in the border regions, and the motives and determinants of corresponding practices in everyday life. Local residents frequently cross the border in search of specific services (e.g. shopping, entertainment, education, health services) or jobs. The authors show that the socio-economic and socio-cultural differences of neighboring states stimulate the emergence of cross-border practices and that these are differentiated according to the properties of the border areas (such as population density, the nature of local economies, connections to large cities and transport networks). The authors conclude that it is more often the case that cross-border interaction is constrained
\end{abstract}


by the lack of corresponding stimuli than emergent obstacles. They also emphasize the constructive role of cross-border practices in maintaining good neighborly relations even in situations of political difficulties.

Key words: state border, everyday life, social practices, Russian borderlands, employment, service market

\section{References}

Andersen D.J. (2013) Exploring the Concept of (Un)familiarity: (Un)familiarity in Border Practices and Identity-Formation at the Slovenian-Croatian Border on Istria. European Planning Studies, vol. 21, no 1, pp. 42-57.

Bille F. (2014) Sovremennost' v prostranstvennom izmerenii: otkrytye rynki, germetichnost' i vertikal'nost' v dvukh prigranichnykh gorodakh Rossii i Kitaya [Modernity in Spatial Dimension: Open Markets, Tightness and Verticality in Two Border Cities of Russia and China]. Ekonomicheskaya sotsiologiya, vol. 15, no 2, pp. 76-95.

Brednikova O.E. (2008) Prigranich'e kak sotsial'nyj fenomen (napravleniya sotsiologicheskoj kontseptualizatsii) [Borderlands as a Social Phenomenon (Directions of Sociological Conceptualization)]. Vestnik Sankt-Peterburgskogo universiteta, Ser. 12, Vyp. 4, pp. $492-497$.

Campbell D. (1992) Writing Security. United States Foreign Policy and the Politics of Identity. Bloomington, IN: Indiana University Press

Cooper A. (2015) Where Are Europe's New Borders? Ontology, Methodology and Framing. Journal of Contemporary European Studies, vol. 23, no 4, pp. 447-458.

Domaniewski S., Studzińska D. (2016) The Small Border Traffic Zone between Poland and Kaliningrad Region (Russia): The Impact of a Local Visa-Free Border Regime. Geopolitics, vol. 21, no 3, pp. 538-555.

Gerasimenko T.I., Filimonova I.Yu. (2011) Orenburgsko-kazakhstanskoe porubezh'e: istorikoetnograficheskij i etnogeograficheskij aspekty [Orenburg-Kazakh Border: Historicalethnographic and Ethno-Geographic Aspects]. Orenburg: Orenburgskij gos. universitet.

Ghosh S. (2011) Cross-border Activities in Everyday Life: the Bengal Borderland. Contemporary South Asia, vol. 19, no 1, pp. 49-60.

Houtum H., Van der Velde M. (2004) The Power of Cross-border Labour Market Immobility. Tijdschrift voor Economische en Sociale Geografie, vol. 95, no 1, pp. 100-107.

Izotov A., Laine J. (2012) Constructing (Un) familiarity: Role of Tourism in Identity and Region Building at the Finnish-Russian Border. European Planning Studies, vol. 21, no 1, pp. 93-111.

Custine de A. (1996) Rossiya v 1839 [Russia in 1839]. Moscow: Izd-vo im. Sabashnikovykh.

Kolosov V.A. (2016) Transgranichnaya regionalizatsiya i frontal'erskie migratsii: evropejskij opyt dlya Rossii? [Cross-border Regionalization and Frontal Migration: European Experience for Russia?]. Regional'nye issledovaniya, no 3 (53), pp. 83-93.

Kolosov V.A., Zotova M.V., Vendina O.I., Sebentsov A.B. (2016) Rossijskoe pogranich'e: sovremennye vyzovy i podkhody k izucheniyu [Russian Borderlands: Modern Challenges and Approaches to Learning]. Problemy regional'nogo razvitiya Rossii [Problems of Regional Development of Russia] (eds. Kotlyakov V.M., Streletskij V.N., Glezer O.B., Safronov S.G.). Moscow: Kodeks, pp. 234-256.

Laine J. (2016) Threats, Challenges, and Finnish-Russian Cross-Border Security Cooperation: A Finnish Perspective. Tourism and Geopolitics: Issues and Concepts from Central and Eastern Europe (ed. Hall D.), pp. 178-191.

Larin V.L. (2008) Mezhregional'noe vzaimodejstvie Rossii i Kitaya v nachale XXI veka: opyt, problemy, perspektivy [Interregional Interaction between Russia and China at the Beginning 
of the 21st Century: Experience, Problems and Prospects]. Problemy Dal'nego Vostoka, no 2 , pp. 40-53.

Newman D. (2002) The Lines that Separate: Boundaries and Borders in Political Geography. A Companion to Political Geography (eds. Agnew J., Toal G.). Oxford: Blackwell, pp. 23-43.

Newman D., Paasi A. (1998) Fences and Neighbours in the Postmodern World: Boundary Narratives in Political Geography. Progress in Human Geography, vol. 22, no 2, pp. 186-207.

Oglezneva E.A. (2011) Yazykovaya situaysiya v Priamur'e: dinamicheskij aspekt. Istorikolingvisticheskij ocherk [Language Situation in the Amur Region: Dynamic Aspect. Historical and Linguistic Essay]. Slovo: fol'klorno-dialektologicheskij al'manakh, no 9, pp. 7-25.

Paasi A. (2009) Bounded Spaces in a 'Borderless World': Border Studies, Power and the Anatomy of Territory. Journal of Power, vol. 2, no 2, pp. 213-234.

Paasi A., Prokkola E.-K. (2008) Territorial Dynamics, Cross-border Work and Everyday Life in the Finnish-Swedish Border Area. Space and Polity, vol. 12, no 1, pp. 13-29.

Pfoser A. (2015) Between Security and Mobility: Negotiating a Hardening Border Regime in the Russian-Estonian Borderland. Journal of Ethnic and Migration Studies, vol. 41, no 10, pp. 1684-1702.

Razowski Ł. (2017) Pół roku bez małego ruchu granicznego. Resort podsumowuje zyski i straty. Olsztyn Onet. Available at: http://olsztyn.onet.pl/pol-roku-bez-malego-ruchu-granicznegoresort-podsumowuje-zyski-i-straty/196zwdm, accessed 30 June 2018.

Schutz A. (2004) Obydennaya $i$ nauchnaya interpretatsiya chelovecheskogo dejstviya [The Ordinary and Scientific Interpretation of Human Action]. Schutz A. Izbrannoe: Mir, svetyashhijsya smyslom [Collected Papers]. Moscow: ROSSPEN, pp. 7-50.

Simutina N.L., Ryzhova N.P. (2007) Ekonomicheskie i sotsial'nye vzaimodejstviya na transgranichnom prostranstve Blagoveshchensk-Hjejhje [Economic and Social Interactions in the Transborder Area of Blagoveshchensk-Heihe]. Vestnik DVO RAN, no 5, pp. 130-144.

Tolstoguzov O.V. (2012) Region v usloviyah globalizatsii: prostranstvennyj i institutsional'nyj aspekty [Region in the Context of Globalization: Spatial and Institutional Aspects]. Trudy KarNC RAN Ser. Region: ekonomika i upravlenie, no 6, pp. 19-28.

Van der Velde B., Spierings B. (2008) Cross Border Shopping and the "Bandwith of Familiarity": Exploring the Positive Impact of National Borders on Consumer Mobility in the Euregion Rhine-Waal. Nijmegen: Nijmegen School of Management. Available at: http://hdl.handle. net/2066/69012, accessed 30 June 2018.

Vendina O.I., Kolosov V.A. (2007) Partnerstvo v obkhod bar'erov [Partnership to Bypass Barriers]. Rossiya v global'noj politike, vol. 5, no 1, pp. 142-154.

Yankov A. G. (2010) Sinofobiya-rusofobiya: real'nost' i illyuzii [Sinophobia-Russophobia: Reality and Illusions]. Sotsiologicheskie issledovaniya, no 3, pp. 65-71.

Zayats D.V., Zotova M.V., Turov N.L., Klyuchnikov M.I. (2017) Krizis rossijsko-ukrainskikh otnoshenij: posledstviya dlya transgranichnykh vzaimodejstvij v Belgorodskoj oblasti [Crisis of Russian-Ukrainian Relations: Effects for Cross-border Interactions in the Belgorod Region]. Izvestiya RAS. Seriya geograficheskaya, no 5, pp. 43-57. 